\title{
The Importance of Strategy Employee Engagement in Organization
}

\author{
Tegar Punang Mahardi*, Dwi Idawati \\ Sekolah Tinggi Manajemen PPM \\ Jakarta, Indonesia \\ *tegarpunang@gmail.com, dwiidawati@gmail.com
}

\begin{abstract}
Employee engagement is a matter of concern for the company to be able to achieve maximum results. Same is the case with PT.XYZ, seeing employee engagement is one of the important things to get maximum results. The current condition with the success rate of employee turnover, makes the company want to see the importance of employee attachment to the company. It will also be seen how employees perceive the company's improvement in an effort to increase employee engagement. The results of employee perceptions are related to three factors that must be improved namely, work environment, infrastructure, and leader support. These factors will design employee engagement strategies so that the company can be designed to achieve maximum results.
\end{abstract}

Keywords-employee engagement, employee engagement strategy, internal communication, competency-based training, leadership skills

\section{INTRODUCTION}

A survey conducted by GALLUP in 2013 on employee engagement in five Southeast Asian countries shows that Indonesia has the lowest number of employee engagement with organizations compared to four other countries. From a survey conducted by GALLUP regarding employee engagement in 2013 , engagement conditions had a level of only $8 \%$ of workers in Indonesia who were engaged in the organization, $77 \%$ of workers were not engaged in the organization, and $15 \%$ of workers were actively disengaged. The low attachment of employees in Indonesia is one of the problems that needs to be considered by every company. Where when this is not used as a problem, it will cause a decline in the industrial sector in Indonesia. This can be seen from the development of industries in Indonesia. If you look at the service industry sector in Indonesia, in 2018 the service industry sector will experience slowing growth. From the Ministry of Industry data, the service sector in 2018 only experienced an increase of 6.48\% compared to 2017 which was $8.91 \%$.

In 2019 from the Ministry of Industry data, the predicted increase in the service industry sector is $8.4 \%$. This statement was strengthened by Setijadi who predicted the logistics sector would grow by $11.56 \%$ [1]. Where the logistics sector is one of the service industries. So in this case by looking at the development of the service industry, every organization engaged in this field must be able to maintain its productivity. One of the organization's efforts in increasing productivity is by tying employees who are assets of the organization.

To achieve success in implementing the strategy, the organization must have human resources that support and have an engagement with the organization. The quality of human resources becomes one of the benchmarks that can support the success of an organization in carrying out strategies. The contribution of human resources will be maximized if every employee has an engagement with the organization. This is because if there is an attachment between the employee and the organization, the employee will be able to improve performance and indirectly the organization's output will also increase.

Kahn defines employee engagement as physical, cognitive and emotional relationships between employee and companies in a job [2]. According to Schaufeli and Bakker employee engagement is a condition of positive thinking for completing work carried out by employees with characteristics in the form of vigor, dedication and absorption [3]. So it can be concluded that employee engagement is an approach in the field of human resource management to provide the best results, has a commitment to the goals and values of the organization, and can motivate itself to be able to contribute to the success of the organization. Employee engagement has a role in the organization including increasing work productivity, work efficiency, reducing employee turnover, and many other benefits. So employees who have engaged with the company will do something more for the company.

In 2019, PT. XYZ experienced organizational downsizing that demanded the performance of each department to be more leverage with existing human resources (HR). After organizational downsizing by $18 \%$, employee turnover maintained has increased. Until May 2019, employee turnover has reached $12 \%$ of the 65 employees retained. High turnover rate is a major problem because PT. XYZ is a holding company that makes policies for each of its business units. PT. XYZ must be able to retain its employees so that the policies set by the organization can work well and can be survive in a business.

From interviews conducted with several employees who resigned, there are several reasons of concern. Some reasons of concern are the unpleasant working environment, especially on social relations between employees, the lack of appreciation from superiors for the performance that has been done, the career path that is considered unclear, and the existence of offers from other companies both from competitors and from other industries.

Various efforts have been made by the HR department to increase employee engagement in the company. From the results of interviews conducted with the HR manager, PT. 
$\mathrm{XYZ}$ has made an effort to bind employees. One of them is by forming $\mathrm{XYZ}$ Community. XYZ Community is a program initiated by the HR department to strengthen relationships between employees based on employees' hobbies and interests. But at the moment the program is not working as desired by the HR department. Besides that, PT. XYZ has provided employee training and development programs. Employee training is carried out from outside the office training using training institutions with the aim of increasing the ability of employees to carry out the responsibilities given by the organization. For employee development, PT. XYZ has created a program intended for all employees, both employees at the center and employees in the business unit. This employee development program aims to increase the agility of each employee and also instill company values.

The design of employee engagement strategies is expected to support the organization's business strategy. The design of this employee engagement strategy will be aligned for the next three years by analyzing existing employees whether they have attachment to the organization. With the design of employee engagement strategies, in addition to being able to support the organization's business strategy, the existing HR in this organization will gain prosperity so that in the future it will create a sense of HR engagement with the organization. This is because human resources are treated and considered their welfare, can improve performance and also the performance of these human resources. The long-term effect is that organizations benefit from the ongoing engagement strategy of employees.

In this study, using employee engagement theory according to Schaufeli and Bakker employee engagement is a condition of positive thinking for completing work owned by employees by emphasizing the characteristics of vigor (strength), dedication, and absorption [3]. The three concepts emphasized in this theory can be used to measure the level of employee engagement in an organization. After that,

\section{MethodOLOGY}

\section{A. Type of Research}

This research uses descriptive quantitative research. Where the purpose of quantitative research is to determine the relationship between variables in a population. The method used in this study is quantitative based on numerical data obtained, where the authors try to find out the conditions of employee engagement with the company so that the data and analysis obtained can design strategies and how they are implemented.

\section{B. Research Instrumen}

The use of Utrecht Work Engagement Scale (UWES) measuring instruments was chosen to measure employee engagement because the measurement tools are academic and have been used by many researchers. In addition, in designing the measuring instrument Schaufeli and Bakker have tested reliability using two ways, namely by using internal consistency and using test-retest reliability [3]. Where the results of the reliability test get results that are not much different between the two events used. The instrument shows in table 1 .
TABLE I. QUESTIONNAIRE INSTRUMENTS MEASURING THE LEVEL OF EMPLOYEE ENGAGEMENT (UWES)

\begin{tabular}{|c|c|c|}
\hline No. & Characteristics & Questionnaire Statement \\
\hline 1. & Vigor & $\begin{array}{l}\text { 1. When working, I feel very excited } \\
\text { 2. At work I feel strong and full of energy } \\
\text { 3. When I wake up in the morning, I'm excited to } \\
\text { work } \\
\text { 4. I can continue to work for a long duration at a tim } \\
\text { 5. I am a person who is tenacious at work } \\
\text { 6. I always persevere at work, even when things } \\
\text { don't go well }\end{array}$ \\
\hline 2. & Dedication & $\begin{array}{l}\text { 1. I see the work I do is very meaningful } \\
\text { 2. I feel enthusiastic about doing my work } \\
\text { 3. My work inspires me } \\
\text { 4. I am proud of the work I am currently doing } \\
\text { 5. For me, my job is very challenging }\end{array}$ \\
\hline 3. & Absorption & $\begin{array}{l}\text { 1. Time passes quickly when I work } \\
\text { 2. When I work, I forget everything around me } \\
\text { 3. I feel happy when I work hard } \\
\text { 4. I am immersed in my work } \\
\text { 5. I am easily engrossed in the tasks that I do } \\
\text { 6. It's hard for me to get away from my job }\end{array}$ \\
\hline
\end{tabular}

Source: Utrecht Work Engagement Scale [3].

In addition, questionnaires were used to analyze the factors that caused employee engagement. The questionnaire was built based on the factors of employee engagement by developing supporting statements. The questionnaire uses a Likert scale with four alternative answers shown in table 2.

TABLE II. THE QUESTIONNAIRE

\begin{tabular}{|c|c|c|}
\hline No. & Factor & Questionnaire Statement \\
\hline 1. & Infrastructure & $\begin{array}{l}\text { 1. The company provides adequate work facilities } \\
\text { for me } \\
\text { 2. The company provides training and } \\
\text { development to employees } \\
\text { 3. The company provides safety and occupational } \\
\text { health facilities } \\
\text { 4. The existence of cooperation between } \\
\text { individuals and between departments involved } \\
\text { in the company }\end{array}$ \\
\hline 2. & $\begin{array}{l}\text { Work } \\
\text { Environment }\end{array}$ & $\begin{array}{l}\text { 1. The company is consistently able to give my } \\
\text { rights as an employee on time } \\
\text { 2. The company tolerates ethnic, religious and } \\
\text { racial diversity } \\
\text { 3. The existence of mutual respect between } \\
\text { employees } \\
\text { 4. The exchange of knowledge or information } \\
\text { related to work, runs smoothly in the company } \\
\text { 5. I rarely think about finding a new job at another } \\
\text { company } \\
\text { 6. I always try to create a comfortable workplace } \\
\text { that makes it easier for my work } \\
\text { 7. Corporate culture has built positive values in me }\end{array}$ \\
\hline 3. & $\begin{array}{l}\text { Work } \\
\text { Weight } \\
\text { Factor }\end{array}$ & $\begin{array}{l}\text { 1. The company highly values the ideas and } \\
\text { suggestions of employees in the company's } \\
\text { development efforts } \\
\text { 2. The company gives me the confidence to do } \\
\text { important work in my department } \\
\text { 3. I am willing to help co-workers to achieve the } \\
\text { goals of the department }\end{array}$ \\
\hline 4. & $\begin{array}{l}\text { Support of } \\
\text { the Leader }\end{array}$ & $\begin{array}{l}\text { 1. There is a warm personal relationship between } \\
\text { superiors and subordinates and between colleagues } \\
\text { in my work unit } \\
\text { 2. My boss builds a professional work atmosphere } \\
\text { to achieve work results that exceed targets } \\
\text { 3. Bosses give encouragement to submit ideas and } \\
\text { suggestions } \\
\text { 4. My supervisor is able to form and foster } \\
\text { collaboration between individuals in the } \\
\text { departments they lead } \\
\text { 5. Bosses provide employee freedom in finding the } \\
\text { most efficient method of completing work }\end{array}$ \\
\hline
\end{tabular}




\section{Data Processing}

The data obtained from the questionnaire is processed every statement by calculating the mean of each statement. Furthermore, the mean of each characteristic is also calculated to determine which characteristics need to be addressed. To find out the level of engagement of employees as a whole, of the three factors the mean is calculated and grouped based on the analysis of conclusions data that has been determined as shown in table 3 .

TABLE III. WeIGHT SCALE CONDITION EMPLOyEe ENGAGEMENT LEVEL

\begin{tabular}{|l|l|}
\hline Alternative Answers & Weight \\
\hline Always & 6 \\
\hline Very often & 5 \\
\hline Often & 4 \\
\hline Sometimes & 3 \\
\hline Rarely & 2 \\
\hline Almost never & 1 \\
\hline Never & 0 \\
\hline
\end{tabular}

Source: Utrecht Work Engagement Scale [3].

Data obtained from each questionnaire were calculated for the mean. After that each of the factors in the questionnaire regarding employee engagement was calculated for its standard deviation. From the overall data obtained entered into an importance performance analysis diagram so that the numerical results obtained from data processing can be placed into the importance performance analysis quadrant. See the table 4 below.

TABLE IV. WEIGHT OF ITEM EMPLOYEE ENGAGEMENT FACTOR SCALE

\begin{tabular}{|l|l|l|}
\hline \multirow{2}{*}{ Weight } & \multicolumn{1}{|c|}{ Performance } & \multicolumn{1}{c|}{ Importance } \\
\cline { 2 - 3 } \multicolumn{1}{|c|}{ Alternative Answers } \\
\hline 1 & Very good & Very important \\
\hline 2 & Well & Urgent \\
\hline 3 & Not good & Not important \\
\hline 4 & Very bad & Very unimportant \\
\hline
\end{tabular}

\section{Analysis and Data Collection}

The survey from the first questionnaire data, which is a survey to find out the condition of the level of employee attachment, was carried out using a questionnaire and obtained numerical data from the SPSS results. The results of SPSS by using descriptive analysis produce data that can be categorized to measure the condition of employee engagement. Shown in table 5 .

TABLE V. MEASURING INTERVAL CONDITIONS FOR EMPLOYEE ENGAGEMENT

\begin{tabular}{|l|l|}
\hline \multicolumn{1}{|c|}{ Interval } & \multicolumn{1}{c|}{ Category } \\
\hline $0-2,33$ & Actively Disengaged \\
\hline $2,34-4,67$ & Not Engaged \\
\hline $4,68-6$ & Engaged \\
\hline
\end{tabular}

Source: Utrecht Work Engagement Scale [3]

The survey from the second questionnaire data, which is a survey of employee engagement factors, was carried out using a questionnaire and obtained numerical data from the SPSS results, to see the gap, the authors used IPA (Importance Performance Analysis) as a benchmark of employee engagement in PT. XYZ There are four quadrants namely the first quadrant is to maintain achievement, the second quadrant is the main priority, the third quadrant is low priority, and the fourth quadrant is excessive. See the table 6 below.

TABLE VI. QUADRANT IMPORTANCE PERFoRMANCE ANALYSIS (IPA)

\begin{tabular}{|c|c|}
\hline $\begin{array}{c}\text { Quadrant II } \\
\text { Main priority }\end{array}$ & $\begin{array}{c}\text { Quadrant I } \\
\text { Maintain } \\
\text { Achievement }\end{array}$ \\
\hline $\begin{array}{c}\text { Quadrant III } \\
\text { Low Priority }\end{array}$ & $\begin{array}{l}\text { Quadrant IV } \\
\text { Exaggerated }\end{array}$ \\
\hline
\end{tabular}

The strategy described in accordance with the four quadrants can be explained as follows:

- Quadrants I (Maintain Achievement): In this quadrant contains factors that are considered important by the organization and factors considered to be an organization that is appropriate so that the level of performance is relatively high. The factors in this quadrant need to be maintained because employees feel engaged to the company.

- Quadrants II (Main Priority): In this quadrant includes factors that are considered important by the organization, but in fact these factors must be increased. This is because employees still do not feel important about employee engagement with the organization.

- Quadrants III (Low Priority): In this quadrant includes factors that are considered less important by the company and in fact employee engagement is not too special. The increase in the factors included in this quadrant needs to be considered because it has an influence on the company.

- Quadrants IV (Exaggerated): In this quadrant includes factors that are considered less important by the company, and are felt to be too excessive.

\section{RESULTS}

\section{A. Analysis Results Utrecht Work Engagement Scale (UWES)}

From the results of the questionnaire to measure employee engagement, the results show that the level of employee engagement at PT. XYZ is not engaged. The lowest value is the absorption characteristic with a mean value of 3.90 and the highest mean value is the dedication characteristic with a mean value of 4.46. All characteristics are at the level of not engaged with a mean value of 4.24 . This result is seen from the measurement analysis which states that the category of not engaged is in the range of values of 2.34-4.67. This causes the employee turnover to be high. With this result the company needs to pay attention to the conditions of employee engagement by evaluating the strategies that have been made regarding employee engagement. See table 7 below.

TABLE VII. EMPLOYEE ENGAGEMENT LEVEL AT PT.XYZ

\begin{tabular}{|l|l|l|l|r|}
\hline Vigor & Dedication & Absorption & Mean & Category \\
\hline 4,37 & 4,46 & 3,90 & 4,24 & Not engaged \\
\hline
\end{tabular}




\section{B. Analysis Results Importance Performance Analysis (IPA)}

In analyzing the factors of employee attachment, a research instrument was built to measure it. Employee engagement factors used in this study after an analysis between the efforts made by PT. XYZ and the theory put forward by Bakker are divided into four factors that cause employee engagement in PT. XYZ These factors are (1) infrastructure and (2) work environment refers to the job resources factor, (3) the weight or demand of the job refers to the salience of job resources, and (4) the leader's support refers to personal resources [5]. See table 8 below.

TABLE VIII. EMPLOYEE ENGAGEMENT FACTOR QUESTIONNAIRE RESULTS

\begin{tabular}{|l|l|l|l|l|}
\hline \multirow{2}{*}{ Factor } & \multicolumn{2}{|c|}{ Mean } & \multirow{2}{*}{ Mean } & $\begin{array}{l}\text { Standard } \\
\text { Deviation }\end{array}$ \\
\cline { 2 - 3 } & Performance & \multicolumn{1}{|c|}{ Importance } & 0,43 & 0,24 \\
\hline Infrastructure & 3,10 & 3,53 & 0,33 & 0,28 \\
\hline $\begin{array}{l}\text { Work } \\
\text { Environment }\end{array}$ & 3,17 & 3,50 & 0,32 & 0,24 \\
\hline $\begin{array}{l}\text { Work Weight } \\
\text { Factor }\end{array}$ & 3,26 & 3,58 & 0,58 & 0,32 \\
\hline $\begin{array}{l}\text { Support of the } \\
\text { Leader }\end{array}$ & 3,01 & 3,59 & 1,61 & 1,05 \\
\hline Total & 12,54 & 14,20 & 0,40 & 0,26 \\
\hline Central Line & 3,13 & 3,55 & &
\end{tabular}

From the results of the questionnaire regarding employee engagement factors will be analyzed using IPA to find out in the quadrant how many employee engagement factors. The results of the analysis using IPA can be seen from the figure 1:

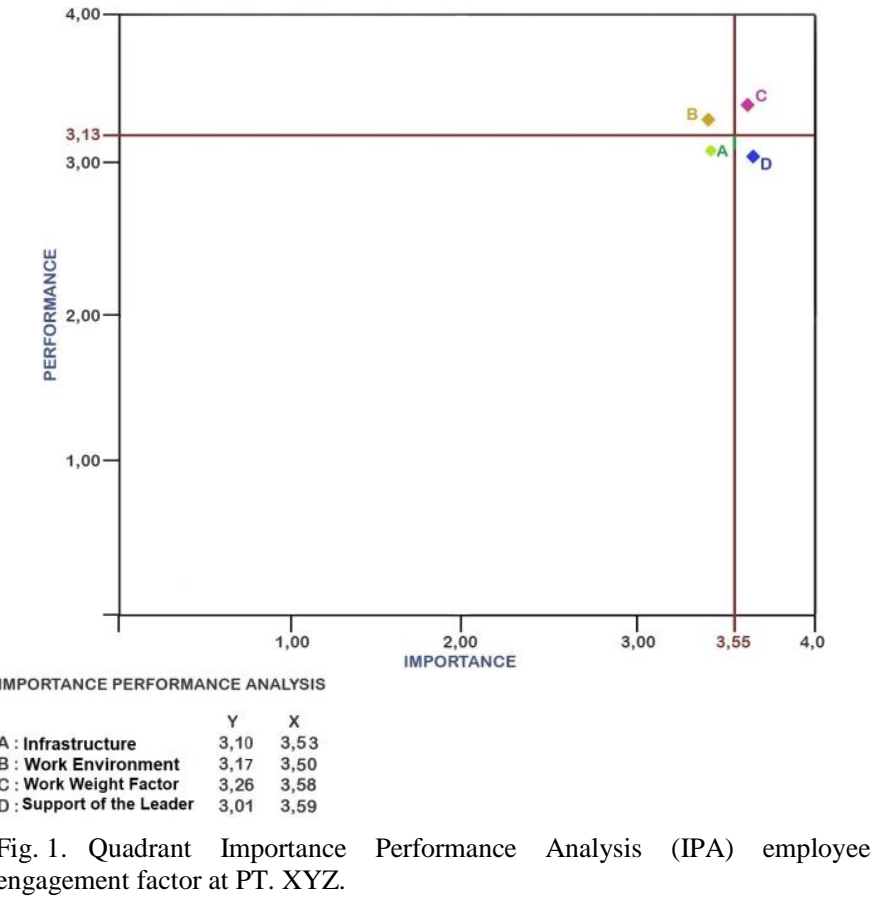

The results of the IPA analysis show that, of the four factors determined, there are three factors of special concern to the company to increase employee engagement at PT. XYZ. These factors are (1) leader support, (2) work environment, and (3) infrastructure. These factors can increase employee engagement in PT. XYZ.

\section{Recap of Problems and Proposed Improvements}

From the explanation of each analysis result, PT. XYZ needs to pay attention to three factors that can increase employee engagement. These three factors are the work environment, infrastructure, and leader support. These three factors will later become the basis for designing employee engagement strategies. In addition to looking at these three factors, the strategy design also looks at the characteristics of the level of employee engagement that is still not engaged. See table 9 below.

TABLE IX. PROBLEMS AND RECOMMENDATIONS FOR IMPROVEMENT

\begin{tabular}{|c|c|c|c|}
\hline UWES & IPA & Problem & $\begin{array}{l}\text { Recommendations for } \\
\text { Improvement }\end{array}$ \\
\hline $\begin{array}{l}\text { Vigor } \\
\text {-Lack of employee morale } \\
\text { when working }\end{array}$ & $\begin{array}{l}\text { Work Environment } \\
\text { •Information exchange }\end{array}$ & \multirow{3}{*}{$\begin{array}{l}\text { - Information exchange is considered to be } \\
\text { lacking, this is because employees still lack } \\
\text { communication within the organization } \\
\text {-Employee training and development as a } \\
\text { means of infrastructure in the organization is } \\
\text { still lacking by employees } \\
\text { - Teamwork is still lacking because according } \\
\text { to employees the leader is still unable to } \\
\text { provide direction to his subordinates }\end{array}$} & \multirow{3}{*}{$\begin{array}{l}\text { - The need to improve } \\
\text { organizational } \\
\text { communication } \\
\text { - Need for competency-based } \\
\text { training and development for } \\
\text { employees } \\
\text { - The need to improve } \\
\text { leadership skills for managers } \\
\text { or departmental leaders }\end{array}$} \\
\hline $\begin{array}{l}\text { Dedication } \\
\text {-The work is less challenging }\end{array}$ & $\begin{array}{l}\text { Work Weight Factor } \\
\text { • Submission of ideas and suggestions }\end{array}$ & & \\
\hline $\begin{array}{l}\text { Absorption } \\
\text {-Lack of appreciation at } \\
\text { work, still think about other } \\
\text { things outside of work }\end{array}$ & $\begin{array}{l}\text { Infrastructure } \\
\cdot \text { Employee training and development }\end{array}$ & & \\
\hline
\end{tabular}

\section{Design Strategy Employee Engagement}

Based on the analysis of recommendations for improving employee engagement at PT. XYZ, has been found to be the basis for designing employee engagement strategies. The three basic factors are the work environment, infrastructure, and leader support. So that the design of employee engagement strategies is focused on these three factors by also taking into account the conditions of the level of employee engagement and the efforts made by the company. See table 10 below. 
TABLE $X . \quad$ TARGET EMPloyeE ENGAGEMENT STRATEGIES

\begin{tabular}{|c|c|c|}
\hline Recommendation & Strategy & Target \\
\hline $\begin{array}{l}\text { Improve } \\
\text { organizational } \\
\text { internal } \\
\text { communication }\end{array}$ & $\begin{array}{l}\text { Building Internal } \\
\text { Communication }\end{array}$ & \multirow{3}{*}{$\begin{array}{l}\text { Reducing the employee } \\
\text { turnover rate in } 2019 \text { by } \\
\text { 12\%. } \\
\text { - } 2020 \text { : Turnover rate drops } \\
\text { to } 8 \% \text { of total employees } \\
\text { - } 2021 \text { : Turnover rate drops } \\
\text { to } 5 \% \text { of total employees } \\
\text { - } 2022 \text { : Turnover rate drops } \\
\text { to } 3 \% \text { of total employees } \\
\text { - } 2023 \text { : Turnover rate drops } \\
\text { to } 1 \% \text { of total employees }\end{array}$} \\
\hline $\begin{array}{l}\text { Competency-based } \\
\text { training } \\
\text { development } \\
\text { employees }\end{array}$ & $\begin{array}{l}\text { Competency } \\
\text { Based Training }\end{array}$ & \\
\hline $\begin{array}{l}\text { Improve leadership } \\
\text { skills for managers } \\
\text { or department } \\
\text { leaders }\end{array}$ & $\begin{array}{l}\text { Improve } \\
\text { Leadership } \\
\text { Ability }\end{array}$ & \\
\hline
\end{tabular}

\section{CONCLUSION}

The results of this study can be concluded that (1) the level of engagement in PT. XYZ is at the level of not engaged. Not engaged levels were obtained from the UWES questionnaire based on the characteristics of vigor, dedication, and absorption. (2) There are four factors carried out by PT. XYZ. to increase employee engagement. These factors are infrastructure, work environment, work weight, and leader support. (3) Employees' perceptions of the efforts made by the company for employee engagement are found to be three factors that need to be corrected. Improved factors are the work environment, infrastructure, and leader support. (4) Three factors that need to be improved are designed strategies to improve employee engagement. The strategy designed is to build internal communication, competency-based training, and improve leadership skills for supervisors both line managers and company leaders.

\section{REFERENCES}

[1] Setijadi, "Sektor Logistik Diprediksi Tumbuh 11,56\% Pada 2019," Supply Chain Indonesia, 2019.

[2] W.A. Kahn, "Psychological conditions of personal engagement and disengagement at Work," Academy of Management Journal Miles, 1990.

[3] E. Schaufeli and A. Bakker, "Utrecht Work Engagement Scale Preliminary Manual," Occupatinal Health Psychology Unit Utrecht University, 2003.

[4] J.A. Martilla and J.C. James, "Importance-Performance Analysis," Journal of Marketing, 1977.

[5] A.B. Bakker, Building Engagement in The Workplace. Rotterdam: Erasmus University, 2007 